\title{
Cognitive Impairment in Schizophrenia, Neurotransmitters and the New Atypical Antipsychotic Aripiprazole
}

\author{
Mariyan K. Topolov' ${ }^{1}$, Damianka P. Getova² \\ ${ }^{1}$ Department of Pharmacology and Drug Toxicology, Faculty of Pharmacy, Medical University of Plovdiv, Plovdiv, Bulgaria \\ 2 Department of Pharmacology and Clinical Pharmacology, Faculty of Medicine, Medical University of Plovdiv, Plovdiv, Bulgaria
}

\section{Correspondence: Mariyan Topo- lov, Department of Pharmacology and Drug Toxicology, Faculty of Pharmacy, Medical University of Plovdiv, Plovdiv, 15A Vasil Aprilov Blvd, 4002 Plovdiv, Bulgaria E-mail:mtopolovmd@gmail.com Tel.: +359893700817}

Received: 01 Nov 2015

Accepted: 04 Feb 2016

Published: 30 April 2016

Key words: aripiprazole, cognition, psychoses

Citation: Mariyan K. Topolov MK Getova DP. Cognitive impairment in schizophrenia, neurotransmitters and the new atypical antipsychotic aripiprazole.

Folia Medica 2016;58(1);12-18, doi: 10.1515/folmed-2016-0002
Cognition is a group of mental processes that includes the capacity to perceive, think, learn and to study, and the capacity of the brain to analyze information and program adaptive behaviour. Although there has been an appreciable evolution in the therapy of psychoses in the last twenty-five years, cognitive disturbances still persist in spite of antipsychotic treatment. The cognitive decay disrupts the ability of clinically diagnosed patients with psychoses, mainly schizophrenia, to learn and to memorize skills that are useful for their family and social relationships. Moreover, cognitive deficiency is often considered to be crucial for further rehabilitation. In atypical antipsychotics there are big differences in the effects on cognitive functions. Some clinical studies demonstrate the benefits of a third generation of antipsychotics on cognitive functions in patients treated for mental illnesses. In the present study we have reviewed many articles investigating the influence of aripiprazole on cognition in human and animal subjects. Aripiprazole is a third generation antipsychotic drug that possesses a unique pharmacodynamic profile, which in conjunction with recently published scientific data on the drugs' influence on antidepressant, anxiolytic and cognitive functions, suggests a highly positive future potential for restorative cognitive treatment and ongoing healthy function. The data included in the review will contribute to determining the potential benefits of aripiprazole on memory and training processes.

\section{INTRODUCTION}

The cognitive deficits in patients with psychosis is one of the prominent dimensions of the mental disorder. The deficit starts early in the course of the disease, even before the other signs manifest themselves - it is profound and pervasive and involves several skills including the working memory, attention and learning. Moreover, it seems that the severity of the deficit is the best predictor of social functioning in the community. In recent years, the cognitive deficit has been in the focus of research. As a result, a battery of cognitive tests was developed and validated as a consensus measure for assessing the deficit and evaluating the effectiveness of novel compounds designed to enhance cognitive function in psychoses like schizophrenia. ${ }^{1}$

\section{HISTORICAL FACTS ABOUT SCHIZOPHRENIA}

Schizophrenia has a lifetime prevalence of $4.0 / 1000$ individuals worldwide. ${ }^{2}$ Positive symptoms (e.g. hallucinations, delusions, deranged thought and be- havior), negative symptoms (e.g. loss of motivation, affective flattening, restricted emotional experience and expression, poverty of speech, reduced hedonic capacity, and cognitive impairment symptomatic of the illness have a persistent negative impact on patients' ability to maintain relationships and engage in productive work. ${ }^{3,4}$ This psychosis is a collection of mental and behavioral phenomena defining a clinical syndrome. Its features may include: abnormal perceptions; aberrant inferential judgements that result in extraordinary beliefs and delusions; distorted thought construction manifested as a disorder language; unusual, often restricted emotion, as well as widespread cognitive problems particularly affecting memory, attention and executive functions. ${ }^{5}$

Both Kraepelin and Bleuler observed difficulties in schizophrenic patients' cognitive processes of attention, memory, and problem solving, and systematic tests were developed by the 1940s; however, much of what is known regarding the cognitive 
impairment in schizophrenia has accrued since a concerted research effort began in the 1980s. ${ }^{6}$ It was Reichenberg and Harvey in 2007 that reported a general review of quantitative reviews from 12 domains, including general intellectual ability, verbal memory, nonverbal memory, recognition, executive functions, motor skills, working memory, language, attention, and processing speed. The main finding, consistent with the older reports, is that patients perform more poorly than healthy controls across all 12 of the neurocognitive domains, the patientcontrol difference averaging between a 0.5 - and 1.5-standard-deviation shift.

\section{COGNITIVE IMPAIRMENT IN SCHIZOPHRENIA}

Cognitive function is markedly impaired in most patients with schizophrenia. Antecedents of this impairment are evident in childhood. Cognitive impairments may have more functional repercussions in adolescents with early-onset psychosis than in adults because they interfere with a period of time crucial for social, emotional, and academic development. Thus, these impairments could result in more disabled occupational functioning, social attainment, and independent living. The cognitive disability is nearly fully developed at the first episode of psychosis in most patients. The contribution of cognitive impairment to outcome in schizophrenia, especially work function, has been established. Preliminary results indicate that cognitive function, along with disorganization symptoms, discriminate schizophrenia patients who are able to work full-time from those who are not. ${ }^{7}$ Patients suffering from this psychosis have widespread, multifaceted impairments in many domains of neurocognitive function, including executive function, attention, perceptual/ motor processing, vigilance, verbal learning and memory, verbal and spatial working memory, and semantic memory (verbal fluency). ${ }^{8}$

Some researchers re-administered the IQ subtests to the 44 individuals who developed schizophrenia and found that, though a few tests showed a decline in performance, there was little change on the majority of the tests, suggesting that a substantial proportion of the intellectual decline occurred prior to the onset of the first psychosis. ${ }^{9}$ It appears that the severity of the cognitive impairment in first-episode schizophrenia is indistinguishable (i.e., on the order of an SD shift, on average, in performance) from the impairment seen in individuals with chronic schizophrenia ${ }^{10,11}$ suggesting that neurocognitive deficiency is one of the stabler aspects of schizophrenia. Adding to this perspective, quantitative reviews suggest that cognitive impairment is one of the best predictors of the poor social and vocational outcomes that are characteristic of a vast majority of individuals with schizophrenia. ${ }^{12}$ An interesting development in the understanding of neurocognition in schizophrenia is the well-replicated finding that genetic relatives of individuals with schizophrenia show an attenuated cognitive impairment that is more severe than healthy controls. ${ }^{13}$ On average, unaffected relatives differ from controls between 0.2 to 0.5 a standard deviation across domains. Raquel and Ruben Gur have reproduced this same pattern of data in a multigenerational family study, demonstrating that neurocognitive domains may be genetic markers for schizophrenia. ${ }^{14}$

\section{THE NEUROTRANSMITTERS INVOLVED IN PSYCHOSIS}

The evolution of various pharmacological therapies for psychoses has given rise to several pharmacological models for the neuroreceptor targets of antipsychotics and the influence of various neuroreceptors on specific symptoms and side effects, and still dominant after decades of research, is the dopamine hypothesis - a model that focuses on imbalances in dopaminergic activity. According to the dopamine hypothesis, hyperactivity of the mesolimbic dopaminergic pathway mediates symptoms of psychosis, while hypoactive dopaminergic pathways mediate negative and cognitive symptoms. Although antipsychotics of first generation such as haloperidol and levomepromazine that inhibit dopamine transmission reduce the activity of hyperactive dopaminergic pathways, they also trigger side effects such as EPS (Extrapyramidal symptoms), and increase prolactin secretion, by diminishing levels of dopamine in pathways where dopamine excess was not initially a problem. ${ }^{15}$ Typical or conventional antipsychotics are effective, with an acute onset of antianxiety effect followed by a reduction in positive symptoms ${ }^{16}$. Compared with placebo relapse rates of upwards of $80 \%$, these drugs also reduce relapses over the course of the illness. Unfortunately, many patients respond very poorly to these dugs. Additionally, typical antipsychotics are of limited effect, and can even worsen negative and depressive symptoms in patients with psychoses. They also have no appreciable effect on cognitive deficits, including memory deficiency, and may even aggravate them. ${ }^{17}$ 
There is considerable preclinical and some clinical evidence that effects on serotonin receptors contribute to the low risk of producing extrapyramidal side effects, which is the defining characteristic of an atypical antipsychotic drug. There is significant antipsychotic action, lack of elevation in plasma prolactin levels and ability to improve some domains of cognition in patients with schizophrenia. The serotonergic actions of the atypical antipsychotic drugs, especially $5-\mathrm{HT}_{2 \mathrm{~A}}$ receptor antagonists, are particularly important to the differential effects of typical and atypical antipsychotic drugs. 5- $\mathrm{HT}_{1 \mathrm{~A}}$ receptor stimulation and $5-\mathrm{HT}_{6}$ and $5-\mathrm{HT}_{7}$ receptor antagonism may contribute to beneficial effects of these agents on cognition. ${ }^{18}$

\section{NOVEL ASPECTS OF THE TREATMENT WITH ATYPICAL ANTIPSYCHOTICS AND THEIR ROLE IN COGNITIVE FUNCTIONING}

The introduction of the second-generation or atypical antipsychotics was a major advance in the pharmacotherapy of schizophrenia. These agents are associated with a substantially lower liability for extrapyramidal adverse effects and a reduced risk of tardive dyskinesia compared with first generation or typical agents. The improved tolerability profile of atypical antipsychotics has been attributed to their serotonin $5 \mathrm{HT} 2 \mathrm{~A}, \mathrm{C}$ receptor antagonism and/or 5HT1A partial agonism in addition to their dopamine D2 receptor antagonism. ${ }^{19}$ All currently available antipsychotic agents, both conventional and atypical, are dopamine D2 receptor antagonists. Blockade of dopamine receptors in the mesolimbic pathway is thought to mediate antipsychotic efficacy, in particular the ability to decrease positive symptoms. ${ }^{20}$ However, D2 receptor blockade in the mesocortical, nigrostriatal, and tuberoinfundibular pathways is correlated with a dysfunctional reward system and increased liability for extrapyramidal symptoms (EPS) and hyperprolactinemia-unwanted side effects of antipsychotic therapy. ${ }^{21}$

The development of D2 partial agonists is a logical strategy for the treatment of schizophrenia because the pathophysiologic mechanism of schizophrenia is thought to be based on too much dopamine activity in some regions of the brain and too little dopamine activity in other regions. A D2 partial agonist can act as a functional antagonist in areas of high levels of dopamine, such as the mesolimbic pathway, but not in areas of normal dopamine levels, such as the nigrostriatal and tuberoinfundibular pathways (Fig. 1). Thus, a D2

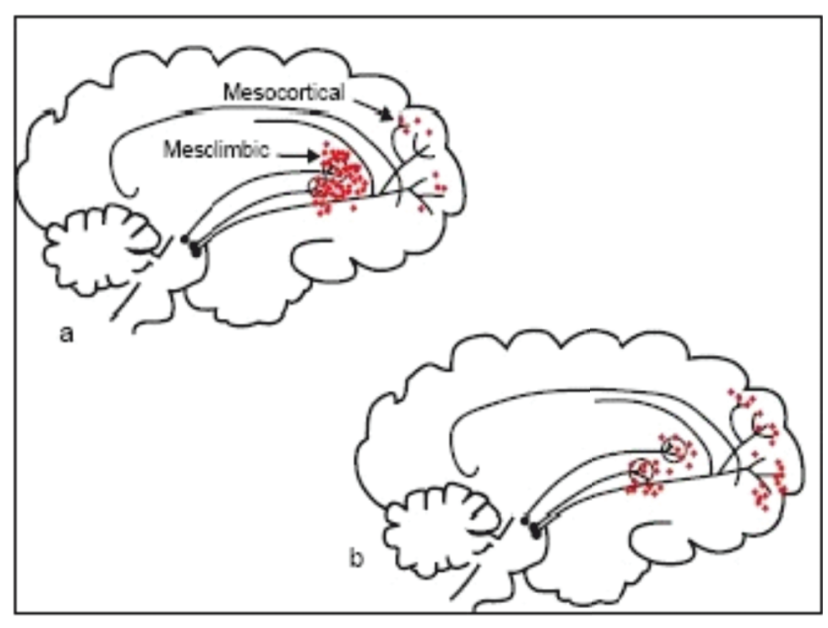

Figure 1. Mesolimbic and mesocortical dopamine pathway activities before (a) and after (b) aripiprazole administration.

partial agonist is expected to reduce the positive symptoms of schizophrenia without producing movement disorders or elevated prolactin levels. In regions of low dopamine concentration, such as the mesocortical pathway, a D2 partial agonist will show functional agonist activity. ${ }^{20}$

\section{ARIPIPRAZOLE - A NEW ANTIPSYCHOTIC}

Recent research has suggested that cognitive disorders are a persistent trait of mental illnesses such as schizophrenia. Cognitive deficits in the course of schizophrenia may be due to the disease and/or drug therapy, especially with old-generation drugs. Several clinical experiments have indicated the beneficial effects of new-generation antipsychotics on cognitive processes in patients treated for mental disorders.

Aripiprazole is a new, atypical antipsychotic with a unique mechanism of action, which may have positive effects on cognitive functions. ${ }^{22}$

\section{Pharmacokinetics}

Aripiprazole is a psychotropic drug that is available as tablets, orally disintegrating tablets, oral solution, and injection. The chemical structure of aripipra-

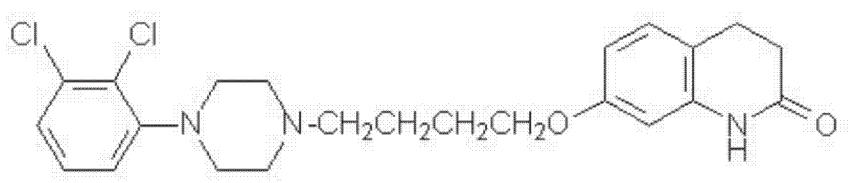

Figure 2. Structural formula of aripiprazole. 
zole is 7-[4-[4-(2,3-dichlorophenyl)-1-piperazinyl] butoxy]-3,4-dihydrocarbostyril. The empirical formula is $\mathrm{C} 23 \mathrm{H} 27 \mathrm{Cl} 2 \mathrm{~N} 3 \mathrm{O} 2$ and its molecular weight is 448.39 (Fig. 2).

Aripiprazole is well absorbed after oral administration, with peak plasma concentrations occurring within 3 to 5 hours; the absolute oral bioavailability is $87 \%$. Aripiprazole can be administered with or without food. Administration of a $15-\mathrm{mg}$ aripiprazole tablet with a standard high-fat meal did not significantly affect the Cmax or AUC (Area under the curve) of aripiprazole or its active metabolite, dehydro-aripiprazole, but delayed Tmax by 3 hours for aripiprazole and 12 hours for dehydro-aripiprazole.

In many pharmacokinetic studies of aripiprazole injection administered intramuscularly to healthy subjects, the median times to the peak plasma concentrations were at 1 and 3 hours. A 5-mg intramuscular injection of aripiprazole had an absolute bioavailability of $100 \%$. The plasma maximum concentration achieved after an intramuscular dose was on average $19 \%$ higher than the Cmax of the oral tablet. While the systemic exposure over 24 hours was generally similar between aripiprazole injection given intramuscularly and after tablet administration, the aripiprazole AUC in the first 2 hours after an intramuscular injection was $90 \%$ greater than the AUC after the same dose as a tablet.

Aripiprazole is metabolized primarily by three biotransformation pathways: dehydrogenation, hydroxylation, and N-dealkylation. Based on in vitro studies, CYP3A4 and CYP2D6 enzymes are responsible for dehydrogenation and hydroxylation of aripiprazole, and N-dealkylation is catalyzed by CYP3A4. Aripiprazole is the predominant drug moiety in the systemic circulation. At steady state, dehydro-aripiprazole, the active metabolite, represents about $40 \%$ of aripiprazole in plasma. Co-administration of aripiprazole with known inhibitors of CYP2D6, like quinidine, results in a $112 \%$ increase in aripiprazole plasma exposure, and dosing adjustment is needed. Paroxetine and other inhibitors of CYP2D6 such as fluoxetine and duloxetine may also increase the plasma levels of aripiprazole if they are co-administered in patients with major depressive disease. On the contrary carbamazepine and possibly other inducers of CYP3A4 decrease plasma levels of aripiprazole. ${ }^{23}$ The mean elimination half-lives are about 75 hours and 146 hours for aripiprazole in extensive metabolizers and poor metabolizers, respectively. Aripiprazole molecule does not inhibit or induce the CYP2D6 pathway. ${ }^{24}$

\section{Pharmacodynamics}

Aripiprazole's mechanism of action is different from the other atypical antipsychotics (e.g., clozapine, olanzapine, quetiapine, ziprasidone, and risperidone). Aripiprazole's dopamine $\mathrm{D}(2)$ and serotonin 5-HT(1A) receptor partial agonist activities have been postulated to confer clinical efficacy without marked sedation, and a relatively favourable overall side-effect profile. Rather than antagonizing the D2 receptor, aripiprazole acts as a D2 partial agonist $(\mathrm{Ki}=0.34 \mathrm{nM}) \cdot{ }^{25}$ Aripiprazole is also a partial agonist at the 5 -HT1A receptor $(\mathrm{Ki}=1.65 \mathrm{nM})$, and like the other atypical antipsychotics displays an antagonist profile at the 5 - $\mathrm{HT} 2 \mathrm{~A}$ receptor $(\mathrm{Ki}=0.8$ $\mathrm{nM}){ }^{26}$ It is the first dopamine $\mathrm{D}(2) / \mathrm{D}(3)$ receptor partial agonist and stabilizer successfully developed and ultimately approved for treatment of a broad spectrum of psychiatric and neurological disorders. Using aripiprazole's unique profile as a benchmark for new dopamine partial agonist development may facilitate discovery of new antipsychotics. ${ }^{27}$ It also antagonizes the 5-HT7 receptor $(\mathrm{Ki}=39 \mathrm{nM})$ and acts as a partial agonist at the 5 -HT2 $\mathrm{C}$ receptor (Ki $=15 \mathrm{nM}$ ), both with high affinity. The latter action may underlie the minimal weight gain seen in the course of therapy. ${ }^{28}$ Aripiprazole has moderate affinity for histamine $(\mathrm{Ki}=61 \mathrm{nM}), \alpha$-adrenergic $(\mathrm{Ki}=57 \mathrm{nM})$, and $\mathrm{D} 4$ receptors as well as the serotonin transporter, while it has no appreciable affinity for cholinergic muscarinic receptors. D2 and D3 receptor occupancy levels are high, with average levels ranging between $\sim 71 \%$ at $2 \mathrm{mg}$ /day to $\sim 96 \%$ at $40 \mathrm{mg} / \mathrm{day} .{ }^{29}$

Recently, it has been demonstrated that in 5-HT7 receptor knockout mice, aripiprazole does not reduce immobility time in the forced swim test (FST), and actually increases it. This implicates 5-HT7 antagonism as playing a major role in aripiprazole's antidepressant effects, similarly to amisulpride. ${ }^{30,31}$

CLINICAL INDICATIONS FOR TREATMENT WITH ARIPIPRAZOLE The efficacy and tolerability of aripiprazole have been demonstrated in various psychiatric diseases. It was originally developed and approved for the treatment of schizophrenia in 2002 and it seems that efficacy is mediated through its unique pharmacological profile. In 2004 aripiprazole has received approval for the treatment of bipolar disorder as adjunctive therapy or monotherapy as well as an augmentation therapy of major depressive disorder in 2007 by the US FDA. There are many clinical 
studies that have proven efficacy of aripiprazole for acute mania and the prevention of mania, thus the available evidence does not support the efficacy of aripiprazole monotherapy in outpatients with bipolar I disorder experiencing a major depressive episode without psychotic features. ${ }^{32}$ The overall safety and tolerability of aripiprazole is favourable compared to other atypical antipsychotics across the approved indications. Aripiprazole shows a minimal propensity for clinically significant weight gain and metabolic disruption. However, extrapyramidal side effects, such as akathisia, are reported and may limit its clinical use in some cases, particularly in patients with bipolar disorder and major depressive disorder. Aripiprazole is an antipsychotic drug which could be useful for a wider spectrum of psychiatric disorders in children and adolescents. Tolerability of aripiprazole in children have been well demonstrated in many clinical studies, which supported approvals granted by the US Food and Drug Administration for irritability associated with autistic disorder in children and adolescents. There is little risk of deterioration such as disinhibition and rapid stabilization is easy to achieve in children and adolescents without definitive diagnoses or with a combination of more than one spectrum of disorders. However, randomized or blind studies are still limited, and the majority of reports referenced here are openlabel studies and case reports. ${ }^{33,34}$ There are also randomized placebo-controlled clinical trials in elderly people that shows aripiprazole's modest efficacy in the treatment of Alzheimer's disease related psychosis. Nevertheless, the medication should be used only in selected patient populations resistant to non-pharmacological treatment with persisting or severe psychotic symptoms and/or agitation, and in which symptoms lead to significant morbidity, patient suffering and potential self-harm. ${ }^{35}$

Aripiprazole have received some attention as potential pharmacotherapy for the treatment of psychostimulant addiction. Some experimental data indicates that acute administration of aripiprazole could decrease cocaine self-administration in rats ${ }^{36}$, moreover one pilot study in humans shows that cocaine craving is decreased significantly with both aripiprazole and ropinirole treatment but aripiprazole is more efficacious in reducing cocaine use ${ }^{37}$.

\section{CONCLUSIONS}

Although schizophrenia is well known and treated psychic disease, research on the neurobiological changes in the brain still continues. Used more than fifty years, modern conventional neuroleptics are being slowly shifted away by the new group of atypical antipsychotics. Aripiprazole as a new medication from this group shows many advantages in the treatment of this disease. Its unique mechanism of action and relatively small number of side effects make it preferred choice especially in young patients and children with schizophrenia.

\section{ACKNOWLEDGEMENTS}

This study is part of Scientific Project No. DP03/2014 of MU-Plovdiv.

\section{REFERENCES}

1. Krivoy A, Fischel T, Weizman A. The cognitive deficit in schizophrenia. Harefuah 2012;151(5):277-80 (Hebrew).

2. Saha S, Chant D, Welham J, McGrath J. A systematic review of the prevalence of schizophrenia. PLoS Med 2005;2:e141.

3. Lieberman JA, Perkins D, Belger A, et al. The early stages of schizophrenia: Speculations on pathogenesis, pathophysiology, and therapeutic approaches. Biol Psychiatry 2002;5:346.

4. Bowie CR, Reichenberg A, Patterson TL, Heaton RK, Harvey PD. Determinants of real-world functional performance in schizophrenia subjects: correlations with cognition, functional capacity, and symptoms. Am J Psychiatry 2006;163:418-425.

5. Jones PB, Buckley PF, Kessler D. Schizophrenia. London: Elsevier, Churchill and Livingstone; 2006; p. 7-18.

6. Goldberg TE, David A, Gold JM. Neurocognitive deficits in schizophrenia. In: Hirsch SR, Weinberger DL, editors. Schizophrenia. 2nd ed. New York: Raven Press; 2003. p. 168-184.

7. Palmer BA, Pankratz, VS, Bostwick JM. The lifetime risk of suicide in schizophrenia: a reexamination. Arch Gen Psychiatry 2005;62(3):247-53.

8. Saykin, AJ, Shtasel DL, Gur RE, et al. Neuropsychological deficits in neuroleptic naive patients with first-episode schizophrenia. Archives of General Psychiatry 1994;51(2):124-131.

9. Caspi A, Reichenberg A, Weiser M, et al. Cognitive performance in schizophrenia patients assessed before and following the first psychotic episode. Schizophr Res 2003;65:87-94.

10. Gold JM, Green MF. Schizophrenia: Cognition. In: Sadock BJ, Sadock VA, eds. Kaplan and Sadock's comprehensive textbook of psychiatry. 8th ed. Philadelphia: Lippincott, Williams \& Wilkins; 2005. p. 1436-48.

11. Keefe RSE, Eesley CE. Neurocognitive impair- 
ments. In: Lieberman JA, Stroup TS, Perkins DO, eds. Textbook of schizophrenia. Washington, DC: American Psychiatric Publishing; 2006. p. 245-60.

12. Green MF, Kern RS, Braff DL, Mintz J. Neurocognitive deficits and functional outcome in schizophrenia: Are we measuring the "right stuff"? Schizophr Bull 2000;26(1):119-36.

13. Reichenberg A, Harvey PD. Neuropsychological impairments in schizophrenia: Integration of performance-based and brain imaging findings. Psychol Bull 2007;153(5):833-58.

14. Gur RE, Nimgaonkar VL, Almasy L, et al. Neurocognitive endophenotypes in a multiplex multigenerational family study of schizophrenia. Am J Psychiatry 2007;164:813-19.

15. Jones PB, Buckley PF, Kessler D. Schizophrenia. London: Elsevier, Churchill and Livingstone 2006. p. 65-89.

16. Emsley R, Oosthuizen P. Evidence based pharmacotherapy of schizophrenia. Int J Neuropsychopharmacol 2004;7(2):219-38.

17. Harvey PD, Keefe RSE. Studies of cognitive change in patients with schizophrenia following treatment with atypical antipsychotics. Am J Psychiat 2001;158:176-84.

18. Meltzer HY, Massey BW. The role of serotonin receptors in the action of atypical antipsychotic drugs. Curr Opin Pharmacol 2011;11(1):59-67.

19. Millan MJ. Improving the treatment of schizophrenia: focus on serotonin (5-HT1A) receptors. J Pharmacol Exp Ther 2000;29:5853-61.

20.Potkin SG, Saha AR, Kujawa MJ, et al. Aripiprazole, an antipsychotic with a novel mechanism of action, and risperidone vs placebo in patients with schizophrenia and schizoaffective disorder. Arch Gen Psychiatry 2003;60(7):681-90.

21. Richelson E. Receptor pharmacology of neuroleptics: relation to clinical effects. J Clin Psychiatry 1999;60(10):5-14.

22.Burda K, Czubak A, Kus K, Nowakowska E, Ratajczak P, Zin J. Influence of aripiprazole on the antidepressant, anxiolytic and cognitive functions of rats. Pharmacol Rep 2011;63(4):898-907.

23.Stahl SM. Stahl's essential psychopharmacology: the prescriber's guide. Antidepressants $4^{\text {th }} \mathrm{ed}$. New York; Cambridge University Press; 2011:22.

24. Kubo M, Koue T, Maune H, et al. Pharmacokinetics of aripiprazole, a new antipsychotic, following oral dosing in healthy adult Japanese volunteers: influence of CYP2D6 polymorphism. Drug Metab Pharmacokinet 2007;22(5):358-66.
25. Burstein ES, Ma J, Wong S, et al. Intrinsic Efficacy of Antipsychotics at Human D2, D3, and D4 Dopamine Receptors: Identification of the Clozapine Metabolite N-Desmethylclozapine as a D2/D3 Partial Agonist. J Pharmacol Exp Ther 2005;315(3):1278-87.

26. Shapiro DA, Renock S, Arrington E, et al. Aripiprazole, a novel atypical antipsychotic drug with a unique and robust pharmacology. Neuropsychopharmacology 2003;28(8):1400-11.

27. Tadori Y, Forbes RA, McQuade RD, et al. In vitro pharmacology of aripiprazole, its metabolite and experimental dopamine partial agonists at human dopamine D2 and D3 receptors. Eur J Pharmacol 2011;668(3):355-65.

28.Zhang JY, Kowal DM, Nawoschik SP, et al. Distinct functional profiles of aripiprazole and olanzapine at RNA edited human 5-HT2C receptor isoforms. Biochem Pharmacol 2006;71(4):521-9.

29. Kegeles LS, Slifstein M, Frankle WG, et al. Dose-Occupancy Study of Striatal and Extrastriatal Dopamine D2 Receptors by Aripiprazole in Schizophrenia with PET and [18F]Fallypride. Neuropsychopharmacology 2008;33(13):3111-25.

30. Hedlund PB. The 5-HT7 receptor and disorders of the nervous system: an overview. Psychopharmacology 2009;206(3):345-54.

31. Sarkisyan G, Roberts AJ, Hedlund PB. The 5-HT7 receptor as a mediator and modulator of antidepressant-like behavior. Behavioural Brain Research 2010;209(1):99-108.

32. Thase ME, Jonas A, Khan A, et al. Aripiprazole monotherapy in nonpsychotic bipolar I depression: results of 2 two randomized, placebo-controlled studies. J Clin Psychopharmacol 2008;28(1):13-20.

33. Kirino E. Efficacy and safety of aripiprazole in child and adolescent patients. Eur Child Adolesc Psychiatry 2012;21(7):361-8.

34. Pae CU. A review of the safety and tolerability of aripiprazole. Expert Opin Drug Saf 2009;8(3):373-86.

35. De Deyn PP, Drenth AF, Kremer BP, et al. Aripiprazole in the treatment of Alzheimer's disease. Expert Opin Pharmacother 2013;14(4):459-74.

36. Thomsen M, Fink-Jensen A, Woldbye DP, et al. Effects of acute and chronic aripiprazole treatment on choice between cocaine self-administration and food under a concurrent schedule of reinforcement in rats. Psychopharmacology (Berl) 2008;201(1):43-53.

37. Meini M, Moncini M, Cecconi D, et al. Aripiprazole and ropinerole treatment for cocaine dependence: evidence from a pilot study. Curr Pharm Des 2011;17(14):1376-83. 


\title{
Когнитивные нарушения шизофрении, нейротрансмиттеры и новый атипический нейролептик арипипразол
}

\author{
Мариян К. Тополов ${ }^{1}$, Дамянка П. Гетова² \\ ${ }^{1}$ Кафедра фармакологии и лекарственной токсикологии, Факультет фармации, Медицинский университет, Пловдив, \\ Болгария \\ 2 Кафедра фармакологии и клинической фармакологии, Факультет медицины, Медицинский университет, Пловдив, \\ Болгария
}

Когниция это познавательный процесс или совокупность психологических процессов, включающий в себя восприятие, познание, мышление, представление, суждение, а также умение мозга анализировать информацию, подстраиваюму под поведение. В последние 25 лет существенно продвинулся процесс лечения психозов, но не смотря на это, нарущения когнитивных функций до сих пор ещё остались, несмотря на антипсихотичную терапию. Упадок когнитивных функций вмешивается в клинически диагностируеммый психоз, наиболее часто шизофрению, возможности пациента обучатся и свойства памяти к запоминанию, что необходимо для семейной и социальной взаимосвязи. Кроме того, возобновление когнитивных функций чаще всего воспринимается как главный этап к полной реабилитации пациента. Среди атипичных нейролептиков существует большая разница воздействия на когнитивные функции.
Некоторые клинические исследования указывают на преймущества воздействия нейролептиков третьего поколения на когнитивные функции, у душевно больных пациентов. В данном обследование изанализированны несколько статей, которые относятся к воздействию арипипразола на когницию людей и животных. Арипипразол нейролептик третьего поколения, которому присущь уникальный фармокодинамиский профиль и вместе с недавно опубликованными данными об его воздействии на атидиприсантную, анксиолитическую и когнитивную функции, считается потенциально успешным средством в будущем, чтобы воздействовать на улудшение когниции и выздоровлении вцелом. Данные приведенные в этом обследование позволяют определить возможные преймущества арипипразола в процессе востоновления памяти и свойств обучения.

Ключевые слова: Арипипразол, когниция, психозы 